\title{
Skuteczność terapii EMDR w zmniejszaniu dystresu psychicznego u osób, które przeżyły katastrofy naturalne - przegląd
}

\author{
Fehimda Natha \\ Anna Daiches \\ Uniwersytet Lancaster
}

\begin{abstract}
Katastrofy naturalne mają wpływ na całe społeczności ludzkie, zarówno w wymiarze indywidualnym, jak i ekonomicznym czy społecznym. Chociaż oddziaływanie tego typu zdarzeń na zdrowie psychiczne ludzi jest ogromne, to wciąż brak adekwatnych środków zaradczych w obszarze zdrowia psychicznego osób, które doświadczyły i przeżyły katastrofy. W ramach programu Humanitarian Assistance Programme, podjęto próbę zajęcia się potrzebami osób, które przeżyły katastrofę naturalną, poprzez wykorzystanie terapii EMDR (Eye Movement Desensitization and Reprocessing). Niniejszy przegląd przedstawia dowody skuteczności terapii EMDR w leczeniu dystresu psychicznego u osób, które wyszły cało z katastrofy naturalnej. Spośród ośmiu omówionych badań, cztery badania były próbami kontrolowanymi, a jedno badanie było kontrolowane częściowo. Wszystkie badania wykazały zarówno statystyczną, jak i kliniczną istotność w redukowaniu intensywności objawów zespołu stresu pourazowego (PTSD), lęku, depresji oraz innych typów dystresu, doświadczanych przez osoby ocalone z katastrof naturalnych. Co więcej, cztery spośród ośmiu badań wykazały istotność kliniczną zaledwie po jednej sesji terapeutycznej. Oznacza to, że EMDR jest terapią pozwalającą zaoszczędzić zasoby, czas oraz koszty. Zagadnieniami omawianymi w niniejszym przeglądzie są ramy teoretyczne, adaptacja podczas interwencji, kwestie metodologiczne oraz ocena jakości badań, jak również implikacje na przyszłość i praktyka kliniczna.
\end{abstract}

Słowa kluczowe: omówienie systematyczne; EMDR; dystres psychiczny; PTSD; katastrofy naturalne.

K

atastrofy naturalne to zdarzenia powodujące ogromne szkody i w istotny sposób zaburzające funkcjonowanie wspólnot ludzkich (Katz, Pellegrino, Pandya, Ng, \& DeLisi, 2002). Ekspozycja na katastrofe naturalną to skomplikowane zjawisko. Zdarzenia tego typu mają bezpośredni wpływ na jednostki - ze względu na zagrożenie życia oraz możliwość doznania innych strat, jak również wpływ pośredni - ze względu na szkody doznane przez daną społeczność i wynikające $z$ tego kłopoty gospodarcze, społeczne oraz administracyjne (Norris \& Wind, 2009). Jak sugerują niektóre badania u osób, które przeżyły katastrofe naturalna, może wystapić trauma i dystres psychiczny (Ursano, Fullerton, Weisaeth, \& Raphael, 2007). Literatura omawiająca kwestie psychologicznego wpływu katastrof często koncentruje się na zespole stresu pourazowego (PTSD). Wśród powodów takiego stanu rzeczy, jest pojmowanie warunkowania strachu na podstawie modeli zwierzęcych, co pozwala pojąć mechanizmy biologiczne leżące u podstaw traumy. Inny powód wiaże sie $z$ interwencjami terapeutycznymi, opartymi na teorii uczenia się, które są skuteczne w przypadku osób doświadczających traumy (Kirmayer, Lemelson, \& Barad, 2007).

Trauma wystepująca po katastrofie może wywołać różne negatywne skutki. Wyczerpujący przegląd

This article originally appeared as Natha Fehmida, Deiches Anna. (2014). The Effectiveness of EMDR in Reducing Psychological Distress in Survivors of Natural Disasters: A Review. Journal of EMDR Practice and Research, 8(3), 157-170. Trans-

lated by Karol Nobis. 
badań nad skutkami katastrof naturalnych, przeprowadzony przez Murthy'ego, Bertolote i Epping-Jordan (2001, cytowany przez Gelbach, 2008) wykazał, że PTSD zaobserwowano u uczestników 74\% badań. Kolejnymi, rzadszymi skutkami, była depresja, leki $\mathrm{i}$ inne formy dystresu. Aby przeciwdziałać pogarszaniu sie zdrowia psychicznego u osób, które przeżyły katastrofe naturalna, opracowano program HAP Humanitarian Assisstance Programme (North, 2007). W celu zaspokojenia długookresowych potrzeb emocjonalnych osób ocalonych $z$ katastrof naturalnych, w ramach tego programu prowadzone są szkolenia terapeutów w zakresie EMDR. Reagowanie na potrzeby zdrowia psychicznego po katastrofie może okazać sie najważniejszym aspektem procesu zdrowienia (Ursano i in., 2007). Niniejszy przegląd koncentruje się na terapii EMDR skierowanej do osób ocalonych z katastrof naturalnych, u których wystepuje dystres psychiczny, rozumiany tutaj jako wszelkie urazy (impairment) bądź negatywne emocje, doświadczane przez osoby, które taką katastrofe przeżyły.

\section{Dystres psychiczny u osób, które przeżyły katastrofę naturalną}

Rośnie liczba występujących na świecie katastrof naturalnych (Gelbach, 2008), znacząca jest również ilość ofiar śmiertelnych na skutek tego typu zdarzeń. Przykładowo, liczba ofiar śmiertelnych w wyniku tsunami na Oceanie Indyjskim w 2004 roku siegnęł 280000 osób, a około 100000 kolejnych zostało zmuszonych do przesiedlenia się na skutek tej katastrofy (Norris \& Wind, 2009). Katastrofy, pociagające za sobą dużą liczbę ofiar, wiążą się ze zwiększonym dystresem psychicznym. Rubonis i Bickman (1991) przeprowadzili meta-analize zwiazków pomiędzy wystepowaniem katastrof a dystresem psychicznym. Stwierdzono, że poziom dystresu był wiekkszy o $17 \%$ w stosunku do okresu przed katastrofąoraz w porównaniu z grupąkontrolna. Co więcej, stwierdzono że zwiększona śmiertelność była ściśle powiazana $z$ dystresem psychicznym, co pozwoliło wyjaśnić $20 \%$ wariancji, gdy kontrolowano pozostałe czynniki. Najprawdopodobniej osoby, które przeżyły katastrofy naturalne pociagające za sobą dużą liczbe ofiar, są bardziej narażone na ryzyko doświadczenia dystresu psychicznego, $z$ uwagi na większe zagrożenie swego własnego życia.

PTSD jest najczęściej diagnozowanym zaburzeniem u osób, które przeżyły katastrofe naturalna, jest też głównym celem interwencji służb odpowiedzialnych za zdrowie psychiczne. Objawy PTSD obejmuja: ponowne doświadczanie negatywnych zdarzeń, unikanie, otepienie lub nadpobudliwość emocjonalną (Terranova, Boxer, \& Morris, 2009). Osoby, u których zdiagnozowano PTSD, mogły bezpośrednio doświadczyć zdarzenia traumatycznego, mogły widzieć, gdy takie zdarzenie dotyka inne osoby lub mogły być narażone na ekspozycję przerażających widoków (North, 2007). Systematyczny przegląd autorstwa Neria, Nandi oraz Galea (2007) ujawnia, że liczba stwierdzonych przypadków PTSD po katastrofach jest znacząca, i że jest to najcześsiej wystepujące zaburzenie na skutek katastrof naturalnych. Jednakże w niedawno opublikowanym badaniu Lo, Su i Chou (2012), stwierdzono, że powiązanie między PTSD a katastrofami jest bardzo zróżnicowane. W dokładniejszym ujęciu, odsetek osób ocalonych $z$ katastrof naturalnych i cierpiacych na PTSD wynosił od $8 \%$ do $34 \% \mathrm{w}$ przypadku trzesienia ziemi w Tajwanie w 1999 r., 25\% w przypadku trzesienia ziemi w Turcji oraz $84 \%$ po trzęsieniu ziemi w Armenii. Co więcej, badania wykazały, że istnieją określone czynniki zwieksszające ryzyko doświadczenia dystresu psychicznego w nastepstwie katastrof naturalnych. Należą do nich: płeć żeńska (Garrison i in., 1995), wcześniejsze problemy psychiczne (Katz i in., 2002), niski poziom wykształcenia (La Greca, Silverman, \& Wasserstein 1998), brak wsparcia społecznego (Vernberg, Greca, Silverman, \& Prinstein, 1996, cytowane przez Northa, 2007) oraz poziom ekspozycji (North, 2007). Zgodnie $z$ powyższym, społeczne teorie poznawcze dowodza, że wsparcie społeczne jest istotnym czynnikiem chroniącym przed wystapieniem dystresu psychicznego. Uważa sie, że działania pomocowe ze strony innych osób ocalonych $z$ katastrofy w efektywny sposób modelują reakcje radzenia sobie oraz mogą ułatwić zdrową adaptację (Benight \& Bandura, 2004, cytowane przez Watson, 2007). Może to zmniejszyć prawdopodobieństwo wystapienia dystresu psychicznego.

Jednakże pozorne korelacje mogą być zniekształcone przez inne czynniki ryzyka (North, 2007). Przykładowo, North, Smith oraz Spitznagel (1994) stwierdzili powiazzanie między niskim poziomem wykształcenia oraz PTSD u ocalonych $\mathrm{z}$ katastrof naturalnych tylko dlatego, że było to widoczne u badanych kobiet, u których symptomy PTSD wystepowały cześciej niż u mężczyzn. Powyższy przykład uświadamia, że wszelkie wnioski należy wyciagać z dużą uwagąi ostrożnością. Co więcej, chociaż badania sugeruja, że kobiety są bardziej narażone na doświadczenie dystresu psychicznego, to dopuszcza się taką możliwość, że mę̇żyźni cześciej stosują samoleczenie, które można traktować jako adaptacyjny mechanizm radzenia sobie. $Z$ tego względu u mężczyzn, którzy przeżyli katastrofe naturalna, 
wykrycie dystresu psychicznego może być trudniejsze. Dla przykładu, Pollice, Bianchi, Roncone i Cassacchia (2011) przeprowadzili badanie ankietowe na grupie 1078 osób ocalałych z trzęsienia ziemi we Włoszech. Badacze stwierdzili istotna korelacje pomiędzy poziomem ekspozycji na katastrofe a nadużywaniem różnych substancji u mężczyzn.

Dystres psychiczny u ocalonych $\mathrm{z}$ katastrof naturalnych obejmuje zaburzenia depresyjne oraz zespół lęku uogólnionego (Kar \& Bastia, 2006). Pierwsze trzy miesiace to okres, w którym ryzyko wystapienia depresji jest największe (Katz i in., 2006). Poziom ekspozycji na katastrofe również zwiększa ryzyko pojawienia sie depresji. Podobnie oddziałuja zdarzenia stresujące, które miały miejsce wcześniej (Kendler, Karowski, \& Prescott, 1998). Osoby ocalałe $z$ katastrofy mogą również doświadczać innych zaburzeń lękowych, takich jak ataki paniki lub fobie (Terranova i in., 2009). Coraz bardziej powszechne jest również współwystępowanie dwóch lub większej ilości problemów związanych ze zdrowiem psychicznym. Przykładowo, Fan, Zhang, Yang, Mo oraz Liu (2011) zbadali wystepowanie dystresu psychicznego u 2250 nastolatków sześć miesięcy po trzęsieniu ziemi w Chinach. Stwierdzono, że u ocalałych osób wystepowało łącznie PTSD, lęk oraz depresja. Niestety, jednym $z$ głównych zastrzeżeń wobec tego badania, jest brak danych dotyczacych uprzednio wystepujących problemów ze zdrowiem psychicznym u badanych osób. Utrudnia to określenie, czy wspomniane objawy powstały na skutek katastrofy.

\section{Doraźne interwencje zmniejszające dystres psychiczny u osób, które przeżyły katastrofę naturalną}

Debriefing psychologiczny definiuje sie jako dyskusje grupowe, odbywajace sie $\mathrm{w}$ czasie 48-72 godzin od traumatycznego zdarzenia (Katz i in., 2002). Sesje zachęcaja pacjentów do eksploracji swych myśli, reakcji i strategii radzenia sobie w nastepstwie zdarzenia traumatycznego (Watson, 2007). Debriefing po katastrofie opiera się na założeniu, że niezwłoczne przetworzenie zdarzenia pozwala ocalonym osobom zbudować jego właściwą strukture poznawcza, dzięki czemu wspominanie go związane jest $z$ mniejszym poziomem stresu (Watson, 2007). Jednakże, jak sugerują niektóre badania, debriefing może być nieskuteczny lub nawet szkodliwy, zwiększając ryzyko powstania długotrwałych objawów psychologicznych (Bisson \& Deahl, 1994). Z tego względu niektórzy badacze postuluja, by zaprzestać stosowania debriefingu jako interwencji (Bisson \& Deahl, 1994).
$Z$ drugiej strony, istnieją dowody przemawiajace za stosowaniem terapii behawioralno-poznawczej (CBT) $\mathrm{w}$ celu zmniejszania intensywności symptomatologii powiązanej ze zdarzeniami traumatycznymi (Seidler $\&$ Wagner, 2006). W podobny sposób De Roos i in. (2011) przeprowadzili losowe porównanie CBT i EMDR aby określić efektywność obu terapii w zmniejszaniu objawów traumatycznych u dzieci, które doświadczyły katastrof. Każdy typ terapii skutkował zmniejszeniem depresji, lęku oraz objawów PTSD, jednakże w przypadku EMDR efekty uzyskano po mniejszej ilości sesji.

Inna teoria - zachowania zasobów Hobfolla (COR) (1989, cytowana przez Lo i in., 2012) zakłada natomiast, że utrata zasobów jest istotnym czynnikiem związanym ze stresem i zdrowiem psychicznym. Implikacje dotyczace interwencji, które wynikają $z$ tej teorii sugeruja, że wzmacnianie zasobów psychicznych i społecznych jest istotnym elementem procesu zdrowienia (Watson, 2007). Wciąż jednak pozostaje niejasne, w jakim stopniu wcześniej wspomniane rodzaje interwencji są skuteczne we wzmacnianiu zasobów (resource investment).

\section{Terapia EMDR w leczeniu dystresu psychicznego u osób, które przeżyły katastrofę naturalną}

EMDR to interwencja terapeutyczna mająca określoną strukture, oparta na modelu adaptacyjnego przetwarzania informacji (AIP), koncentrująca się na sposobie przechowywania wspomnień oraz procesie przetwarzania informacji (Shapiro \& Maxfield, 2002). Model tej terapii zakłada, że podstawą bieżącego dystresu psychicznego są emocje i doznania psychiczne, zwiąane $z$ nieprzetworzonymi zdarzeniami traumatycznymi oraz ich nieprawidłowym przechowywaniem w strukturach pamieci (Van Rood \& de Roos, 2009). W terapii EMDR pacjent jest proszony o przywołanie określonego wspomnienia, dotyczącego traumatycznego zdarzenia, i jednoczesne śledzenie ruchów ręki, wykonywanych przez terapeute.. Uważa się, że stymulacja bilateralna wraz $z$ docieraniem do nieprzetworzonych wspomnień traumatycznych uruchamia układ przetwarzania w mózgu i ułatwia asymilacje traumatycznego wspomnienia oraz włączenie go w większą sieć pamięciową (Solomon \& Shapiro, 2008). Tym samym, traumatyczne wspomnienie nie jest już odizolowane, dzięki czemu zachodzi proces adaptacyjny, będacy skutkiem nowych połączeń w mózgu.

$\mathrm{Na}$ podstawie metaanaliz dowiedziono efektywności terapii EMDR w leczeniu PTSD (Bisson \& Andrew, 2009; Davidson \& Parker, 2001). W podobny sposób Roos, Benjamin, De Roos, 
Mejier oraz Stams (2009) przeprowadzili metaanalizę skuteczności EMDR u dzieci, potwierdzając jej efektywność. Ponadto, stosowanie EMDR dało nieco lepsze wyniki w terapii dzieci, niż CBT. W przypadku katastrof naturalnych, terapia EMDR okazuje się skuteczna w zmniejszaniu dystresu psychicznego, w tym objawów PTSD (Chemtob, Nakashima, \& Carlson, 2002; Fernandez, Gallinari, \& Lorenzetti, 2004), lęku, depresji oraz strachu. Przykładowo, Jayatunge (2008) ukazał, że na skutek terapii EMDR znacznie zmniejszyła się intensywność objawów, takich jak uczucia depresyjne, leki, natręctwa i koszmary senne u siedmiu osób, które ocalały z tsunami w 2004 roku. Terapia pozwoliła też odbudować funkcjonowanie psychospołeczne, umożliwiając tym osobom prowadzenie normalnego życia. Kolejnym dowodem skuteczności EMDR jest opisany przez Ichii (1997) przypadek dwóch kobiet ocalałych po trzesieniu ziemi i odczuwających dystres psychiczny i które doświadczyły efektywności terapii już po jednej sesji EMDR. Podczas kolejnej sesji sprawdzającej, która miała miejsce pięć miesięcy później, stwierdzono, że efekty leczenia utrzymują sie.

\section{Protokoły powiązane z EMDR}

Różne publikacje definiują terapię EMDR na różne sposoby. Skrót nazwy może sugerować, że w trakcie terapii zostanie zastosowany standardowy protokół, jednak czasem jest on modyfikowany na potrzeby konkretnego przypadku. Przykładem protokołu powiazanego $z$ EMDR i dotyczacego katastrof naturalnych jest Integracyjny, Grupowy Protokół EMDR - EMDR Integrative Group Treatment Protocol (EMDR-IGTP), stosowany przez Jarero, Artigas i Hartung'a (2006). Protokół ten opracowano jako reakcję na katastrofy o znacznym zasiegu. Osiem standardowych sesji EMDR włączono w model terapii grupowej, co pozwala dotrzeć do większej liczby osób ocalonych z katastrofy. Innym protokołem dopasowanym do potrzeb jest Protokół EMDR dla Niedawnych Krytycznych Wydarzeń - EMDR Protocol for Recent Critical Incidents (EMDR-PRECI). Protokół ten różni się od standardowego tym, że pacjent proszony jest o opisanie zdarzenia traumatycznego $\mathrm{w}$ formie narracji oraz o konceptualizacje katastrofy jako rozbudowanego wydarzenia obejmującego sekwencję istotnych i charakterrystycznych zdarzeń, raczej w formie trwającego, ciagkego wydarzenia traumatycznego, niż jako kilku odrębnych zdarzeń (Jarero, Artigas, \& Luber, 2011). Co więcej, w EMDR-PRECI jako stymulację bilateralną stosuje sie głównie "uścisk motyla" (naprzemienne poklepywanie rękami skrzyżowanych na klatce piersiowej ramion) oraz ruch gałek ocznych, natomiast w standardowym protokole EMDR stosuje sie różne formy stymulacji bilateralnej. Niektóre publikacje proponuja komputerową formę EMDR (Abbasnejad, Mehani, \& Zamyad, 2007). Oprogramowanie do przeprowadzania stymulacji bilateralnej, autorstwa Manfielda i Manfielda (2002, cytowane przez Abbasnejad i in., 2007) o nazwie "There and Back", to pakiet oferujący różne rodzaje stymulacji bilateralnej (wizualna, dźwiękowa, dotykowa).

\section{Założenia niniejszego przeglądu}

Chociaż metaanalizy potwierdzają skuteczność terapii EMDR, to przytoczone prace koncentrują się tylko na PTSD, a nie omawiają aspektów związanych z katastrofami naturalnymi. Jak wspomniano wcześniej, ofiary katastrof naturalnych mogą doświadczać różnych negatywnych emocji. Rosnaca liczba katastrof naturalnych na świecie, a co za tym idzie, konieczność zajęcia sie emocjonalnymi potrzebami ofiar tych katastrof, uzasadniają stworzenie szczegółowego opracowania, dotyczacego jedynie przypadków katastrof naturalnych. Ponadto, ze wzgledu na koszty i czas, stosowanie EMDR wobec ofiar katastrof naturalnych wymaga systematycznego potwierdzania, aby ten rodzaj terapii można było polecać jako skuteczną i rozsądną interwencję terapeutyczną w przypadku tego typu zdarzeń.

\section{Metoda}

\section{Wybór opracowań}

Przeprowadzono wyszukiwanie opublikowanych raportów na temat stosowania EMDR u osób ocalonych z katastrof naturalnych. Dla celów niniejszego przeglądu zastosowano trójstopniową strategie wyszukiwania. Poczatkowo prowadzono wyszukiwanie opracowań w komputerowych bazach danych: Journal of EMDR Practice and Research oraz w cyfrowej bibliotece Francine Shapiro Library. Drugim krokiem było zastosowanie metody pochodzenia (ancestry method), w celu odszukania dodatkowych badań na temat stosowania EMDR u osób ocalonych $z$ katastrof naturalnych. Badań tych szukano w bibliografiach opracowań, metaanaliz i artykułów. Ostatnim etapem był kontakt $z$ pracownikiem Francine Shapiro Library oraz z prezesem brytyjskiego stowarzyszenia EMDR $z$ pytaniem o ostatnio opublikowane opracowania dotyczace katastrof naturalnych. Wykorzystano również instrukcje szkoleniową EMDR, zawierająca wykaz artykułów na temat EMDR recenzowanych przez ekspertów i pisma fachowe.

Przeprowadzono również systematyczne wyszukiwanie odpowiednich badań w pięciu głównych 
bibliotecznych bazach danych: PsychINFO, CINAHL, Medline, Academic Search Complete oraz Science Direct. W każdej bazie danych stosowano kluczowe pojęcia: „odczulanie za pomocą ruchu gałek ocznych/ EMDR” LUB „dystres psychiczny” ORAZ „katastrofy naturalne". Zastosowano różnorodne warianty słowne w odniesieniu do tych trzech kluczowych pojeć, w różnej kolejności. Wyszukiwanie obejmowało nastepujące pojęcia dotyczące określonego dystresu psychicznego: „stres posttraumatyczny/PTSD” LUB , stres” LUB „trauma” LUB ,lęk” LUB ,depresja” LUB ,negatywne emocje” LUB „,strach” LUB ,żal” LUB „natrętne myśli” LUB „psychopatologia”. Wariacje słowne dotyczace katastrof naturalnych obejmowały takie pojęcia jak „krytyczny incydent” LUB „kryzys” LUB „powódź” LUB „tsunami” LUB ,trzęsienie ziemi” LUB „wulkan” LUB „,huragan”. Warianty słowne dotyczace EMDR obejmowały nastepujące elementy „EMD” LUB „EMDR-PRECI” LUB „Protokół Grupowy EMDR” LUB „EMDR-IGTP”.

Sprawdzono wszystkie streszczenia a nastepnie pobrano i dokładniej sprawdzono opracowania, które mogłyby spełniać kryteria, pozwalające uwzglednić je jako źródło w niniejszym przeglądzie.

\section{Kryteria wyboru}

Pozycje uwzględnione $\mathrm{w}$ niniejszym przeglądzie to opracowania ilościowe, mierzace skuteczność EMDR u osób ocalałych z katastrof naturalnych. Decyzje o wyszukiwaniu tylko opracowań recenzowanych przez ekspertów i pisma fachowe oraz kompletnych artykułów, podjęto przed rozpoczęciem wyszukiwania pozycji opublikowanych między rokiem 1989 (poczatki EMDR) a 2012. Specyficzne kryteria uwzględnienia danego źródła obejmowały: (a) próby losowe i kontrolowane (RCT - randomized controlled trial), (b) próby nielosowe i niekontrolowane, jeśli obejmowały zatwierdzone pomiary wyników lub jeśli w próbach tych wykorzystywano dokładne instrumenty samoopisu, (c) artykuły recenzowane przez ekspertów, dostepne tylko w j. angielskim, (d) stosowanie standardowego protokołu EMDR oraz protokołów powiazanych z EMDR, oraz (e) opracowania polecające EMDR osobom ocalałym $z$ katastrof naturalnych, doświadczającym różnych form dystresu psychicznego.

Z opracowania wyłączono artykuły nie recenzowane przez ekspertów lub pisma specjalistyczne, takie jak studia przypadku, artykuły wstepne oraz wydania specjalne. Kolejnym krokiem było wyłączenie artykułów opisujących zastosowanie EMDR w leczeniu ofiar katastrof wywołanych przez człowieka.
Z 33 wyszukanych artykułów, 25 nie spełniało kryteriów pozwalajacych uwzględnić je w przeglądzie. Były to artykuły teoretyczne lub opracowania dyskusyjne, studia przypadku lub też nie były recenzowane przez pisma specjalistyczne oraz ekspertów. Dodatkowo, wykluczono opracowania niezwiazane $z$ tematem niniejszego przeglądu, tj. opisujące terapie w przypadku katastrof spowodowanych przez człowieka. Dwa artykuły wykluczono z powodu braku dostepności całego tekstu w języku angielskim oraz braku analiz statystycznych lub opisu wartości/metod pomiarów wynikowych. Ostatecznie, w opracowaniu uwzględniono osiem artykułów.

\section{Ocena jakości}

W niniejszym opracowaniu jakość badań oceniono za pomocą skali o nazwie Zrewidowany Złoty StandardRevised Gold Standard (RGS), która obejmuje zdefiniowane kryteria oceny metodologii badania wyników terapii. Pierwszą wersje, zawierająca siedem standardów, opracowali Foa oraz Meadows (1997). Maxfield i Hyer (2002) zmodyfikowali skale GS (Gold Standard), wprowadzając trzy dodatkowe elementy, które miały zwiekkszyć dokładność pomiarów i ewentualnych niedociagnięć metodologicznych. Ponieważ niniejszy przegląd bada obszar dystresu psychicznego (czego cześciąjest PTSD), elementów GS1 oraz GS10 nie uwzględniono jako kryteriów jakościowych, ponieważ te elementy mierzą tylko PTSD. Finalnie uwzględniono osiem punktów GS (patrz Tabela 1).

Kryteria oceniono za pomocą trzypunktowej skali Likerta dla każdego elementu: 1 punkt przyznawano badaniu spełniającemu wszystkie kryteria, 0,5 punktu przyznawano badaniom cześsiowo spełniajacym kryteria, natomiast 0 uzyskiwały opracowania nie spełniające określonych kryteriów. Opracowanie określano jako „wysokiej jakości”, gdy uzyskało co najmniej 6 punktów „,,umiarkowanej jakości” (4-5 punktów) oraz „niskiej jakości” (4 punkty lub mniej).

\section{Wyniki}

\section{Rodzaje opracowań}

Na osiem opracowań, w czterech zastosowano losowe próby kontrolowane (RCT) (Abbasnejad i in., 2007; Chemtob i in., 2002; Grainger, Levin, Allen-Byrd, Doctor, \& Lee; Jarero i in., 2011), w jednym - badanie cześsiowo kontrolowane (Konuk i in., 2006), a w trzech opracowaniach - badania niekontrolowane (Aduriz, Blughten, \& Knopfler, 2011; Fernandez, 2007; Jarero i in., 2006). W opracowaniu cześciowo kontrolowanym porównano wyniki po leczeniu $\mathrm{w}$ grupie poddanej 


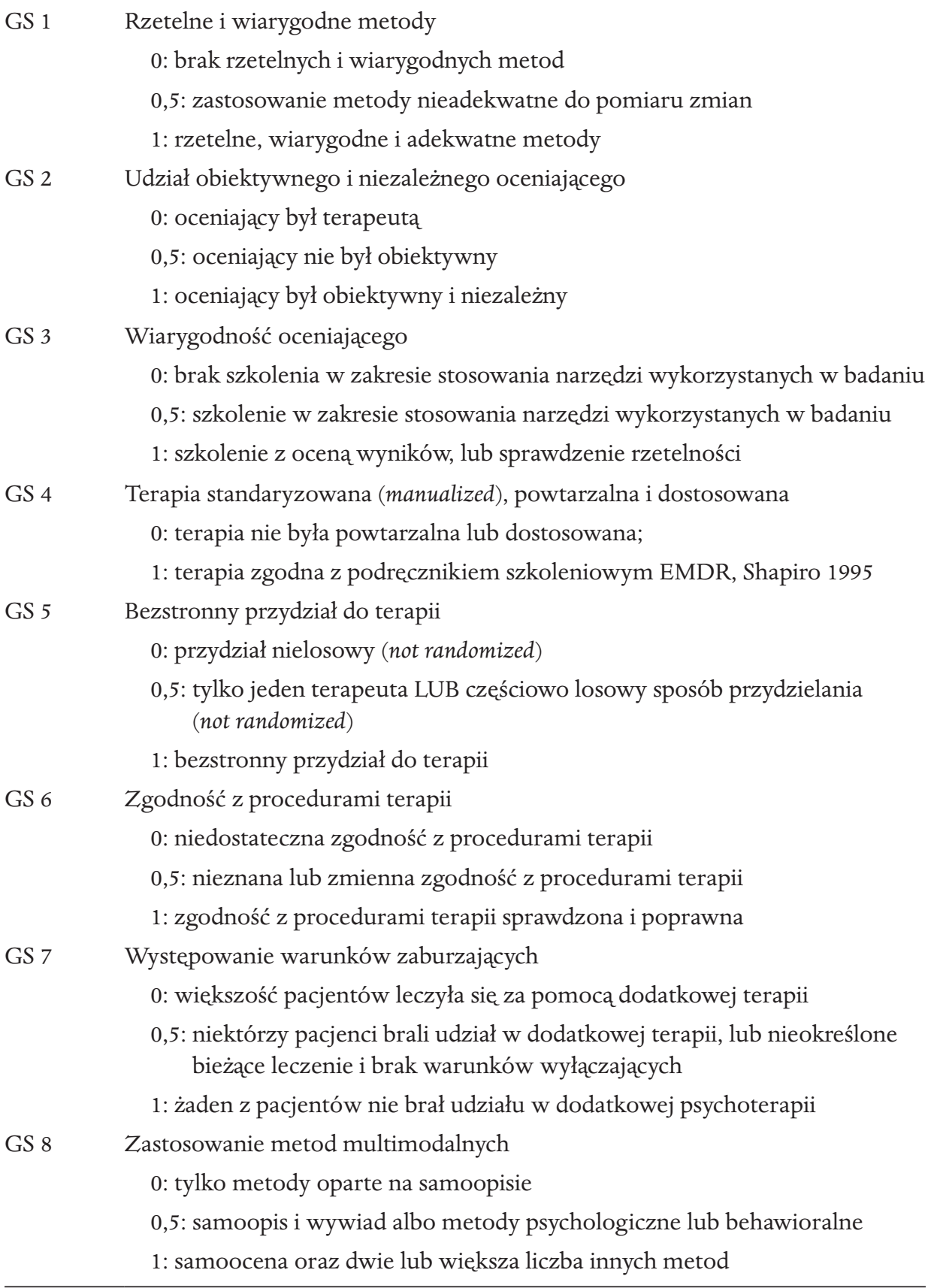

Uwaga. GS = Gold Standard. Zaadaptowano $\mathrm{z}$,"The Relationship Between Efficacy and Methodology in Studies Investigating EMDR Treatment of PTSD" autorstwa L. Maxfield'a oraz L. Hyer'a, 2002, Journal of Clinical Psychology, 58, s. 31.

wczesnej terapii $z$ wynikami przed leczeniem grupy poddanej późnej terapii. W opracowaniach RCT uwzględniono osoby $\mathrm{z}$ grupy kontrolnej, znajdujace się na liście oczekujących na leczenie. Omówienie charakterystyki opracowania znajduje się w Tabeli 2.

\section{Schematy badań}

We wszystkich opracowaniach zastosowano schemat badania pretest-posttest oraz badanie kontrolne (follow-up). Jednakże w przypadku jednego opracowania $\mathrm{w}$ fazie kontrolnej dostępnych było tylko $21 \mathrm{pa}-$ cjentów spośród 41 początkowo leczonych (Konuk i in., 2006). Okres pomiarów następczych wahał się od jednego miesiąca do jednego roku.

\section{Uczestnicy}

Całkowita liczebność próby w niniejszym przeglądzie wyniosła 362 uczestników. Płeć badanych określono w 


\begin{tabular}{|c|c|c|c|c|c|c|c|c|c|}
\hline Autorzy & Katastrofa & $N$ & Typ badania & $\begin{array}{l}\text { Typ dystresu } \\
\text { psychicznego }\end{array}$ & $\begin{array}{l}\text { Protokół } \\
\text { EMDR }\end{array}$ & $\begin{array}{l}\text { Ilość sesji } \\
\text { terapeutycznych }\end{array}$ & $\begin{array}{l}\text { Zastosowane } \\
\text { instrumenty } \\
\text { pomiarowe }\end{array}$ & $\begin{array}{l}\text { Badanie } \\
\text { kontrolne } \\
\text { (Follow-up) }\end{array}$ & $\begin{array}{l}\text { Twierdzenia } \\
\text { dotyczące } \\
\text { efektywności }\end{array}$ \\
\hline $\begin{array}{l}\text { Abbasnejad } \\
\quad \mathrm{i} \text { in. (2007) }\end{array}$ & $\begin{array}{l}\text { Trzesienie ziemi, } \\
\text { Barn, Iran }\end{array}$ & 41 & Badanie RCT & $\begin{array}{l}\text { Objawy PTSD, } \\
\text { lęk, depresja, } \\
\text { strach, fobia, } \\
\text { żal oraz inne } \\
\text { nieprzyjemne } \\
\text { uczucia }\end{array}$ & $\begin{array}{l}\text { EMDR kom- } \\
\text { puterowe } \\
\text { ("There and } \\
\text { Back") }\end{array}$ & 4 & $\begin{array}{l}\text { BDI, BAI i } \\
\text { SUD }\end{array}$ & 1 miesiąc & $\begin{array}{l}\text { Tak, jeśli } \\
\text { uzasadnione }\end{array}$ \\
\hline $\begin{array}{l}\text { Aduriz i in. } \\
\quad(2011)\end{array}$ & $\begin{array}{l}\text { Powódź, Santa } \\
\text { Fe, Argentyna }\end{array}$ & 124 & Niekontrolowane & Objawy PTSD & EMDR-IGTP & 1 & $\begin{array}{l}\text { CRTES, } \\
\text { SUD }\end{array}$ & 3 miesiące & $\begin{array}{l}\text { Tak, jeśli } \\
\text { uzasadnione }\end{array}$ \\
\hline $\begin{array}{l}\text { Chemtob } \\
\text { i in. (2002) }\end{array}$ & $\begin{array}{l}\text { Huragan Iniki, } \\
\text { Hawaje }\end{array}$ & 32 & Badanie RCT & $\begin{array}{c}\text { PTSD, lęk i } \\
\text { depresja }\end{array}$ & Standardowy & 3 & $\begin{array}{l}\text { CRI, } \\
\text { RCMAS, } \\
\text { CDI }\end{array}$ & 6 miesięcy & $\begin{array}{l}\text { Tak, jeśli } \\
\text { uzasadnione }\end{array}$ \\
\hline $\begin{array}{l}\text { Fernandez } \\
\qquad(2007)\end{array}$ & $\begin{array}{l}\text { Trzęsienie } \\
\text { ziemi, Molise, } \\
\text { Włochy }\end{array}$ & 22 & $\begin{array}{l}\text { Niekontrolo- } \\
\text { wane badanie } \\
\text { terenowe }\end{array}$ & PTSD & Standardowy & 8 & $\begin{array}{l}\text { Ocena na } \\
\text { podstawie } \\
\text { SCID-1 }\end{array}$ & $1 \mathrm{rok}$ & $\begin{array}{l}\text { Tak, jeśli } \\
\text { uzasadnione }\end{array}$ \\
\hline $\begin{array}{l}\text { Grainger } \\
\quad \mathrm{i} \text { in. (1997) }\end{array}$ & $\begin{array}{l}\text { Huragan Andrew, } \\
\text { Floryda }\end{array}$ & 40 & Badanie RCT & Objawy PTSD & Standardowy & 1 & IES, SUD, & $\begin{array}{l}1 \text { i } 3 \\
\text { miesiące }\end{array}$ & $\begin{array}{l}\text { Tak, jeśli } \\
\text { uzasadnione }\end{array}$ \\
\hline $\begin{array}{l}\text { Jarero } \mathrm{i} \text { in. } \\
\qquad(2006)\end{array}$ & Powódź, Meksyk & 44 & $\begin{array}{l}\text { Niekontrolo- } \\
\text { wane badanie } \\
\text { terenowe }\end{array}$ & Objawy PTSD & EMDR-IGTP & 1 & $\begin{array}{l}\text { CRTES, } \\
\text { SUD }\end{array}$ & 1 miesiąc & $\begin{array}{l}\text { Tak, jeśli } \\
\text { uzasadnione }\end{array}$ \\
\hline $\begin{array}{l}\text { Jarero } \mathrm{i} \text { in. } \\
\qquad(2011)\end{array}$ & $\begin{array}{l}\text { Trzessienie ziemi, } \\
\text { Meksyk }\end{array}$ & 18 & $\begin{array}{l}\text { Badanie RCT } \\
\text { terenowe }\end{array}$ & Objawy PTSD & EMDR-PRECI & 1 & IES & 3 miesiące & $\begin{array}{l}\text { Tak, jeśli } \\
\text { uzasadnione }\end{array}$ \\
\hline $\begin{array}{l}\text { Konuk } \mathrm{i} \text { in. } \\
(2006)\end{array}$ & $\begin{array}{l}\text { Trzęsienie ziemi, } \\
\text { Marmara, } \\
\text { Turcja }\end{array}$ & $\begin{array}{c}41 \text { (21 osób } \\
\text { podczas } \\
\text { follow-up) }\end{array}$ & $\begin{array}{l}\text { Częściowo } \\
\text { kontrolowane }\end{array}$ & PTSD & Standardowy & 5 & $\begin{array}{l}\text { PSS-SR, SUD, } \\
\text { VOC }\end{array}$ & 6 miesięcy & $\begin{array}{l}\text { Tak, jeśli } \\
\text { uzasadnione }\end{array}$ \\
\hline
\end{tabular}

Uwaga BDI = Beck Depression Inventory; BAI = Beck Anxiety Inventory; SUD = Subjective Units of Disturbance; CRTES = Child's Reaction to Traumatic Events Scale; CRI = Children's

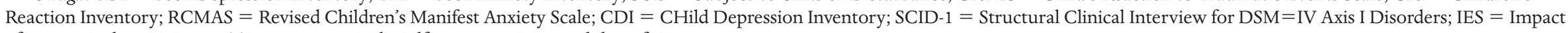
of Events Scale; PSS-SR = PTSD symptom Scale-Self Report; VOC = Validity of Cognitions. 
każdym opracowaniu oprócz opracowania autorstwa Fernandez (2007), która opisała 22 pacjentów. Wśród pozostałych 340 pacjentów, 147 stanowili mężczyźni a 193 kobiety. Wiek badanych wynosił od 6 do 80 lat, przy czym cztery opracowania dotyczyły wyłącznie dzieci ocalałych $z$ katastrof naturalnych (Aduriz i in., 2011, Chemtob i in., 2002; Fernandez, 2007; Jarero i in., 2006). Dzieci te wybrano za pośrednictwem szkół, do których uczeszczały.

\section{Rodzaje dystresu psychicznego oraz}

wcześniejsze występowanie i współwystępowanie innych zaburzeń zdrowia psychicznego

Typy dystresu psychicznego wystepującego u uwzględnionych osób obejmowały klinicznie zdiagnozowane PTSD (Chemtob i in., 2002; Fernandez, 2007; Konuk i in. 2006); objawy PTSD stwierdzone za pomoca samoopisu (Aduriz i in., 2011) lub jednocześnie wystepujace zdiagnozowane PTSD/ objawy PTSD oraz lęk i objawy depresji (Abbasnejad i in., 2007; Chemtob $i$ in., 2002). Abbasnejad i in. (2007) opisali również osoby, u których stwierdzono fobie, żal, strach oraz inne „nieprzyjemne emocje”. Nie jest jednak jasne, czy zostało to stwierdzone przez lekarzy przed skierowaniem na leczenie za pomoca terapii EMDR czy też na podstawie objawów stwierdzonych przez samych pacjentów. Czas wystepowania objawów u uczestników wynosił od 2 tygodni po katastrofie (Jarero i in., 2011) (tu celem było zapewnienie terapii EMDR jako wczesnej interwencji) do 3,5 roku (Chemtob i in., 2002), gdzie inna psychoterapia, stosowana rok przed badaniem, okazała się nieskuteczna w redukowaniu objawów stresu.

Oprócz opracowania Jarero i in. (2006), w żadnym z pozostałych nie opisano okoliczności uprzedniego wystepowania lub współwystepowania dwóch lub większej liczby problemów ze zdrowiem psychicznym. Autorzy zgromadzili pełną historie kliniczną od rodziców i nauczycieli dzieci biorących udział w badaniu. Niestety, w opracowaniu nie określono wyraźnie, jakich objawów, oprócz PTSD, doświadczały dzieci. Nie wspomniano również nic o naturze współwystępujących problemów psychicznych. Co więcej, w opracowaniu Konuka i in. (2006) postanowiono wyłączyć osoby, u których stwierdzono objawy psychozy, zaburzenia dysocjacyjne lub takie, które stanowiły zagrożenie dla samego pacjenta lub innych osób. Jednakże wspomnianych zaburzeń nie wykryto w grupie uczestników badania. Co więcej, Fernandez (2007) zastosowała ocenę PTSD w oparciu o Ustrukturalizowany Wywiad Kliniczny do Badania Zaburzeń z Osi I DSM-IV (SCID-1). Reasumując, opis uprzednio wystepujących lub współwystepujących problemów psychicznych był stosunkowo skapy we wszystkich opracowaniach.

Monoterapia (Single Treatment) lub terapia łączona. Oprócz opracowania Konuka i in., żadne inne nie określiło, czy uczestnicy badania byli leczeni za pomocą innej terapii oprócz EMDR. W ramach grup, niektórzy uczestnicy zażywali przepisane leki przed terapiąlub w jej trakcie. Niemniej jednak pięciu z sześciu uczestników biorących leki przerwało ich przyjmowanie $\mathrm{w}$ okresie między terapią a badaniem kontrolnym (follow-up). Analizy statystyczne wykazały dodatkowo, że przyjmowanie leków nie miało ani pozytywnego ani negatywnego wpływu na leczenie za pomocą EMDR.

\section{Wyniki badań}

W ogólnym ujęciu, terapia EMDR wykazuje istotność statystyczną i kliniczną w zmniejszaniu dystresu psychicznego, co opisano w opracowaniach. Stwierdzono istotne różnice między średnimi wynikami przed terapia, po terapii oraz $\mathrm{w}$ czasie badania kontrolnego (patrz Tabela 3).

Rezygnacja $z$ terapii. Żaden $z$ uczestników badań opisanych w opracowaniach nie odmówił udziału w terapii. W czterech opracowaniach nie odnotowano rezygnacji (Abbasnejad i in., 2007; Grainger i in. 1997; Jarero i in., 2006; Jarero i in. 2011), a uczestnicy przeszli pełny program terapeutyczny. W badaniach Aduriz i in. (2011) oraz Chemtob i in. (2002) dwie osoby zrezygnowały, a dwie nie ukończyły terapii. W badaniu Fernandez (2007) trzy osoby zrezygnowały, w opracowaniu Konuka i in. (2006) 10 osób zrezygnowało, a 7 osób nie ukończyło terapii. Te siedem osób nie wzieło udziału w pomiarach wyników po terapii, mimo iż kontynuowali oni leczenie. W zwiazku z tym, wspomniane opracowania uwzgledniły $\mathrm{w}$ analizach tylko tych uczestników, którzy poddali się pomiarom przed i po leczeniu oraz wykonali pełny program terapeutyczny. Jedynie w opracowaniu Konuka i in. (2006) starano się sprawdzać efekty leczenia u osób, które nie ukończyły programu. W badaniu Jarero i in. (2011), EMDR zastosowano tylko wobec 18 osób, które uzyskały więcej niż 44 punkty w Skali Wpływu Zdarzeń (Impact of Events Scale) - IES; Horowitz, Wilner, \& Alvarez, 1979) po wstepnej interwencji zarządzania kryzysowego, w której udział wzieło 53 pracowników firmy.

Miary wyników. We wszystkich opracowaniach zastosowano jeden miernik wyników lub kombinacje pomiarów podstawowych i pomocniczych. W trzech 
TABELA 3. Średnie wyniki narzędzi pomiarowych, wyników przed i po terapii oraz podczas badań kontrolnych (follow—up)

\begin{tabular}{|c|c|c|c|c|c|c|c|c|c|}
\hline \multirow[b]{2}{*}{ Autorzy } & \multirow[b]{2}{*}{ Narzedzia pomiarowe } & \multirow[b]{2}{*}{ Warunki } & \multicolumn{2}{|c|}{ Przed terapią } & \multicolumn{2}{|c|}{ Po terapii } & \multicolumn{2}{|c|}{ Follow-up } & \multirow[b]{2}{*}{ Istotność } \\
\hline & & & $M$ & $S D$ & $M$ & $S D$ & M & $S D$ & \\
\hline \multirow{6}{*}{$\begin{array}{l}\text { Abbasnejad i in. } \\
(2007)\end{array}$} & \multirow[t]{2}{*}{ BDI } & Eksperymentalne & 33,51 & 6,63 & 16,42 & 4,54 & 15,42 & 5,75 & \multirow[t]{2}{*}{$p<0,001$} \\
\hline & & Opóźnione & 34,45 & 6,56 & 31,55 & 8,84 & - & - & \\
\hline & \multirow[t]{2}{*}{ BAI } & Eksperymentalne & 33,80 & 5,69 & 16,19 & 6,54 & 13,57 & 6,27 & \multirow[t]{2}{*}{$p<0,001$} \\
\hline & & Opóźnione & 33,60 & 7,02 & 31,8 & 8,58 & - & - & \\
\hline & \multirow[t]{2}{*}{ SUD } & Eksperymentalne & 7,19 & 1,36 & 2,57 & 1,03 & 2,21 & 1,32 & \multirow[t]{2}{*}{$p<0,001$} \\
\hline & & Opóźnione & 7,37 & 1,03 & 6,40 & 2,12 & - & - & \\
\hline \multirow{2}{*}{$\begin{array}{l}\text { Aduriz } \mathrm{i} \text { in. } \\
(2011)\end{array}$} & CRTES & Eksperymentalne & 26,40 & - & - & - & 10,80 & & $p<0,001$ \\
\hline & SUD & Eksperymentalne & 7,20 & - & 2,19 & - & - & - & $p<0,001$ \\
\hline \multirow{6}{*}{$\begin{array}{l}\text { Chemtob i in. } \\
(2002)\end{array}$} & \multirow[t]{2}{*}{ CRI } & Eksperymentalne & 36,54 & 11,57 & 16,47 & 12,98 & 10,59 & 8,23 & \multirow[t]{2}{*}{$p<0,001$} \\
\hline & & Opóźnione & 39,60 & 21,04 & 22,60 & 20,21 & 18,87 & 20,39 & \\
\hline & \multirow[t]{2}{*}{ RCMAS } & Eksperymentalne & 18,00 & 5,87 & 14,29 & 8,26 & 10,00 & 8,28 & \multirow[t]{2}{*}{$p<0,001$} \\
\hline & & Opóźnione & 18,07 & 8,17 & 11,78 & 10,99 & 13,57 & 9,47 & \\
\hline & \multirow[t]{2}{*}{ CDI } & Eksperymentalne & 55,94 & 9,86 & 48,71 & 13,03 & 48,35 & 14,22 & \multirow[t]{2}{*}{$p<0,01$} \\
\hline & & Opóźnione & 59,73 & 19,84 & 53,87 & 21,82 & 51,67 & 18,34 & \\
\hline Fernandez (2007) & Ocena na podstawie SCID-1 & Eksperymentalne & - & - & - & - & - & - & $p<0,01$ \\
\hline \multirow{4}{*}{$\begin{array}{l}\text { Grainger } i \text { in. } \\
\text { (1997) }\end{array}$} & \multirow[t]{2}{*}{ IES } & Eksperymentalne & 37,39 & - & 21,60 & - & 24,33 & - & \multirow[t]{2}{*}{$p<0,001$} \\
\hline & & Opóźnione & 18,73 & - & 21,57 & - & - & - & \\
\hline & \multirow[t]{2}{*}{ SUD } & Eksperymentalne & 7,72 & 1,58 & 1,94 & 2,05 & - & - & \multirow[t]{2}{*}{$p<0,001$} \\
\hline & & Opóźnione & 34,36 & - & 37,91 & - & - & - & \\
\hline \multirow[t]{2}{*}{ Jarero i in. (2006) } & CRTES & Eksperymentalne & 32,77 & - & - & - & 8,27 & - & \multirow[t]{2}{*}{ Istotne klinicznie } \\
\hline & SUD & Eksperymentalne & 9,24 & - & 1,29 & - & - & - & \\
\hline \multirow[t]{2}{*}{ Jarero $\mathrm{i}$ in. (2011) } & IES & Eksperymentalne & 54,22 & 11,00 & 24,89 & 4,83 & 22,67 & 4,85 & $p<0,001$ \\
\hline & & Opóźnione & 55,67 & 8,37 & 49,22 & 8,03 & 22,78 & 5,47 & \\
\hline $\begin{array}{l}\text { Konuk i in. } \\
(2006)\end{array}$ & PSS-SR & $\begin{array}{l}\text { Łączone średnie grupy } \\
\text { wczesnej i późnej terapii }\end{array}$ & 34,29 & 7,96 & 5,37 & 4,76 & 7,76 & 7,79 & $p<0,001$ \\
\hline & SUD & Laczone & 8,15 & 2,21 & 0,42 & 0,79 & - & - & $p<0,01$ \\
\hline & VOC & Lączone & 2,34 & 1,44 & 6,42 & 1,08 & - & - & \\
\hline
\end{tabular}

Uwaga: BDI = Beck Depression Inventory; BAI = Beck Anxiety Inventory; SUD = Subjective Units of Disturbance; CRTES = Child's Reaction to Traumatic Events Scale; CRI = Children's

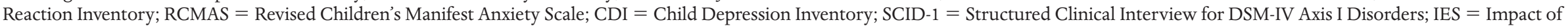
Events Scale; PSS-SR = PTSD Symptom Scale-Self-Report; VOC = Validity of Cognitions. 
opracowaniach (Chemtob i in., 2002; Fernandez 2007; Konuki in., 2006) określono u uczestników status PTSD za pomoca nastepujących instrumentów: PTSD Symptom Scale-Self-Report (PSS-SR; Foa i in., 1993), Child Reaction Index (CRI, Pynoos i in., 1987) oraz bezpośrednio za pomoca kwestionariusza, przygotowanego przez National Institute of Health and Clinical Excellence (NICE, 2005) w oparciu o SCID-1. Natomiast Konuk i in. (2006) nie przedstawiają nazwy zastosowanego narzeddzia pomiarowego. Instrument CRI to wywiad przeprowadzany przez lekarza i służący do identyfikacji PTSD $\mathrm{u}$ dzieci. Instrument ten charakteryzuje się dużą powtarzalnością pomiarową (test-retest reliability), a w opracowaniu Chemtob i in. (2002) uzyskano poziom wartości alfa równy 0,87 . Abbasnejad i in. (2007) zastosowali jako dodatkowe narzędzie pomiarowe irańską wersje Kwestionariusza Pomiaru Depresji Becka (Beck Depression Inventory - BDI) oraz Kwestionariusz Pomiaru Leku Becka (Beck Anxiety Inventory - BAI).

Dodatkowo, w czterech opracowaniach (Aduriz i in., 2011; Grainger i in. 1997; Jarero i in., 2006; Jarero $i$ in, 2011) zastosowano skalę IES lub jej wersję dla dzieci: Skala Reakcji Dzieci na Zdarzenia Traumatyczne (Children's Reaction to Traumatic Events Scale; CRTES; Jones, 1997). Instrumenty te, wykorzystujące metode samoopisu, pozwalają oszacować zakres takich objawów PTSD jak intruzja oraz unikanie. Instrumenty IES oraz CRTES charakteryzują sie wysoką powtarzalnością pomiaru, wiarygodnością oraz dobra spójnością wewnętrzną. W niektórych opracowaniach zastosowano również dodatkowe instrumenty „pomiaru przetworzenia” - Subiektywne Jednostki Dystresu - Subjective Unit of Disturbance (SUD) oraz Skale Wiary w Siłe Przekonania - Validity of Cognitions (VoC). Za pomocą tych narzędzi badano uczestników na różnych etapach terapii. Między opracowaniami, w których zastosowano te instrumenty, wystepowały różnice co do czasu ich zastosowania (tylko przed i po każdej sesji terapeutycznej lub też wielokrotnie po każdej fazie EMDR). Ta rozbieżność metodologiczna ogranicza możliwość porównania wyników przedstawionych w poszczególnych opracowaniach.

Analizy statystyczne. Analiza różnic między grupami oraz wewnatrz grup w czterech randomizowanych badaniach kontrolowanych (RCT) oraz jednym kontrolowanym cześciowo wykazała, że EMDR jest skuteczną metodą zmniejszania dystresu psychicznego. W czterech badaniach zastosowano analize wariancji (ANOVA; Aduriz i in., 2011; Chemtob i in. 2002; Grainger $i$ in., 1997; Konuk $i$ in. 2006), w dwóch badaniach zastosowano test t-Studenta (Abbasnejad i in. 2007; Jarero i in., 2011), a w jednym badaniu zastosowano test znakowanych rang Wilcoxona dla par obserwacji (Fernandez, 2007). W kolejnym badaniu przedstawiono tylko średnie wartości, uznając EMDR jako metode istotną statystycznie (Jarero i in., 2006). Co więcej, Chemtob i in. (2002) zmierzyli również liczbę wizyt szkolnej pielegniarki po terapii oraz postrzeganie przez dzieci terapii i jej użyteczności. Fernandez (2007) nie przedstawiła żadnych średnich ani odchyleń standardowych, podając tylko istotność statystyczną porównania pomiędzy pierwszym i ostatnim pomiarem.

\section{Ocena jakości}

Tabela 4 przedstawia ocene jakości metodologicznej badań. Ogólna ocena waha sie od „wysokiej” do „umiarkowanej”. Jakość czterech badań oceniono jako „wysoką" (Chemtob i in., 2002; Fernandez 2007; Jarero i in., 2011; Konuk i in. 2006). W czterech

\section{TABELA 4. Ocena jakości poszczególnych opracowań przy zastosowaniu skali Revised Gold Standard}

\begin{tabular}{lccccccccc}
\hline Autorzy & $\# 1$ & $\# 2$ & $\# 3$ & $\# 4$ & $\# 5$ & $\# 6$ & $\# 7$ & $\# 8$ & Ocena jakości - wynik \\
\hline Abbasnejad i in. (2007) & 1 & 0 & 0,5 & 0 & 1 & 0,5 & 0,5 & 0 & 3,5 \\
Aduriz i in. (2011) & 1 & 0 & 0,5 & 0 & 0 & 0,5 & 0,5 & 0 & 2,5 \\
Chemtob i in. (2002) & 1 & 0 & 1 & 1 & 1 & 1 & 0,5 & 1 & 6,5 \\
Fernandez (2007) & 1 & 1 & 1 & 1 & 0 & 1 & 0,5 & 0,5 & 6 \\
Grainger i in. (1997) & 1 & 0 & 1 & 1 & 1 & 0,5 & 0,5 & 0,5 & 6,5 \\
Jarero i in. (2006) & 1 & 0 & 0,5 & 1 & 0 & 1 & 0,5 & 0 & 6 \\
Jarero i in. (2011) & 1 & 0 & 1 & 1 & 1 & 1 & 1 & 0 & 6 \\
Konuk i in. (2006) & 1 & 0 & 1 & 1 & 0,5 & 1 & 0,5 & 1 & 6
\end{tabular}


opracowaniach stosowano testy kontrolowane lub częściowo kontrolowane oraz dwa lub większą liczbe narzędzi pomiarowych o dobrej dokładności. Ponadto, w czterech badaniach zastosowano standardowy protokół terapii (Shapiro, 1995), pozwalający na łatwa replikacje badania. W szczególności badanie Fernandez (2007), było jedynym, gdzie aby zredukować efekt oczekiwań i uprzedzeń, wykorzystano obiektywnych oceniających, zarówno do przeprowadzenia oceny jak i diagnozy. W dwóch opracowaniach, których jakość oceniono jako „niską" (Abbasnejad i in., 2007; Aduriz i in., 2011), zastosowano zmodyfikowaną wersje protokołu standardowego i narzędzia pomiarowe wykorzystujace jedynie metode samoopisu. Dwa badania były badaniami niekontrolowanymi. Wszystkie opracowania, oprócz jednego, uzyskały wynik 0,5 w punkcie RGS7, ponieważ nie sprecyzowano w nich, czy badane osoby były leczone jednocześnie za pomocą innej terapii lub też nie wskazały tego jako kryterium wyłączającego. W połowie opracowań opierano się na narzędziach samoopisu. W niektórych opracowaniach brakowało wyjaśnienia, w jaki sposób autorzy zapewniali zgodność z procedurami leczenia lub zgodność poziomu szkolenia osób oceniających. Jednakże ze względu na fakt, że terapeuci należeli do zespołów odpowiedzialnych za zdrowie psychiczne (mental health response team), przyjmuje się założenie, że poziom wyszkolenia tych osób jest wystarczający do przeprowadzenia terapii EMDR i zagwarantowania, że terapia będzie zgodna $z$ programem leczenia. Dlatego też takie opracowania otrzymały wynik 0,5 .

Tylko dwa opracowania poruszały kwestie czynników zakłócających, takich jak płeć (Aduriz i in., 2011) lub wykształcenie (Konuk i in., 2006). Wyniki SUD były dużo wyższe w przypadku dziewczynek niż chłopców, a niski poziom wykształcenia był odwrotnie skorelowany $z$ intruzywnymi obrazami przed terapią, stanem wzmożonej czujności oraz koszmarami. żadne $\mathrm{z}$ opracowań nie zawierało wzmianek na temat mocy testów (power issues) ani nie określało wielkości uzyskanych efektów. Mimo iż wszystkie opracowania wykazały skuteczność EMDR (istotną statystycznie i klinicznie), to większość $z$ nich opierała się na grupie badanych liczaçcych mniej niż 45 osób. Z tych względów opis i dyskusja mocy testów oraz wielkość efektów byłaby istotna.

\section{Dyskusja}

\section{Podsumowanie wyników}

Systematyczny przegląd dostarcza dowodów na skuteczność terapii EMDR w zmniejszaniu dystresu psychicznego u osób, które przeżyły katastrofe naturalna. Potwierdza to osiem opisanych tu opracowań: cztery badania RCT, jedno cześciowo kontrolowane oraz trzy niekontrolowane. Chociaż większość opracowań koncentruje się na objawach PTSD, uzyskane wyniki nie ograniczają sie tylko do tego zaburzenia. Wykazano statystyczną i kliniczną istotność odnośnie redukcji lęku, depresji, strachu, żalu i fobii. Co więcej, cztery z ośmiu opracowań koncentrowały sie na pacjentach dziecięcych, co pozwala rozciagnać uzyskane wyniki również na te grupe. We wszystkich badaniach zastosowano schemat badania pretest-posttest oraz zgromadzono dane weryfikujace (follow-up). Efekty uzyskane w czasie terapii były nadal widoczne w czasie badania kontrolnego, kiedy można było oczekiwać, że ofiary będą doświadczać dalszych negatywnych doznań w wyniku katastrofy. Jest to zgodne $z$ modelem AIP Shapiro (2001) - odpowiednie przetworzenie zdarzenia traumatycznego zmienia sposób, w jaki przechowywane jest ono w sieci pamiecciowej, dzieki czemu trauma nie jest ponownie wyzwalana przez podobne zdarzenia.

Co więcej, ilość sesji terapeutycznych była stosunkowo niewielka - od jednej do ośmiu. Zmniejsza to prawdopodobieństwo wpływu innych czynników (np. zmiana okoliczności życiowych) na wyniki uzyskane w opracowaniach. Niektóre opracowania wskazuja, że miała miejsce tylko jedna sesja terapeutyczna w oparciu o protokół standardowy lub jego pochodne. Dowodzi to, że EMDR jest metoda pozwalającą oszczędzić czas i środki finansowe w leczeniu dystresu psychicznego u osób, które przeżyły katastrofy naturalne. Dlatego niniejszy przegląd przedstawia terapie EMDR jako skuteczną forme w opanowywaniu kryzysu powstałego na skutek takich katastrof.

Biorąc jednak pod uwage, że w trzech opracowaniach stosowano próby niekontrolowane, a jedno było jedynie cześciowo kontrolowane, trudno jest wykazać, że zaobserwowane efekty nie były skutkiem placebo lub spontanicznego wyzdrowienia. $Z$ drugiej strony, prawdopodobieństwo tego jest zminimalizowane ze wzgledu na fakt, że uczestnicy badań doświadczali symptomów przez okres od 2 tygodni do 3,5 roku po katastrofie. Co więcej, w dwóch opracowaniach (Chemtob i in., 2002; Jarero i in. 2011) zwrócono uwage, że osoby były uprzednio (rok wcześniej) leczone za pomocą psychoterapii lub brały udział w szkoleniu zarządzania kryzysem, i każda $z$ tych metod okazała sie nieskuteczna w zmniejszaniu dystresu psychicznego. Dlatego też EMDR można uznać za metodę bardziej skuteczną niż inne sposoby leczenia traumy. 
Ograniczenia niniejszego badania

Mimo że badania RCT zapewniają najbardziej wiarygodne informacje, dotyczące efektów leczenia, ich zastosowanie w przypadku osób, które przeżyły katastrofy naturalne jest trudne $z$ powodów etycznych i ograniczeń logistycznych. Niemniej jednak cztery spośród ośmiu opracowań przedstawiały badania kontrolowane, w których wykorzystano schemat listy oczekiwania/opóźnienia leczenia. Schemat listy oczekiwania jest krytykowany za brak odpowiedniej kontroli czynników sugerujących hipotezę badawcza, z czego może wynikać, że jakakolwiek interwencja jest lepsza niż jej brak. Ten problem jest mniej istotny w opracowaniach, w których uprzednio zastosowane terapie określono jako nieefektywne (ze względu na uporczywy charakter objawów).

Po drugie, w czterech opracowaniach (z czego trzy oceniono jako „wysokiejjakości”) stwierdzono, że cześć badanych osób przerwało leczenie lub go nie ukończyło. $Z$ tego powodu $\mathrm{w}$ analizach statystycznych opracowań uwzględniono tylko te osoby, które ukończyły pełny program leczenia. $\mathrm{W}$ konsekwencji powoduje to pewną stronniczość selekcji, faworyzującajeden typ interwencji oraz obniża wiarygodność takich opracowań. Przyszłe opracowania powinny stosować metodologie, uwzględniającą cheć do podjęcia leczenia, która ujmuje $\mathrm{w}$ analizach osoby przerywające lub nie kończace terapii. Pomogłoby to zachować rzetelność badań. Takie ograniczenia sprawiają natomiast, że badacze są mniej skłonni do wyciagania wiażących wniosków na podstawie powyższych opracowań.

Opis czynników zakłócających wyniki był niedostateczny w przedstawionych opracowaniach, z wyjątkiem opracowań Aduriza i in. (2011) oraz Konuka $i$ in. (2006). Brak wykształcenia wiazano $z$ wyższą podatnością na kryzys w sytuacji katastrofy naturalnej (Garrison i in., 1995), natomiast w opracowaniu Konuka i in. (2006) stwierdzono, że niższe wykształcenie było powiązane $z$ bardziej negatywnymi skutkami. Wiedza zdobyta w wyniku edukacji może stanowić dla danej osoby ochrone przed utratą lub brakiem poczucia kontroli, a także ułatwić radzenie sobie ze stresem. Jako że cztery opracowania przedstawiały wyniki badań dzieci wybranych za pośrednictwem szkół, z założenia przyjęto określony poziom wykształcenia. Omówienie wpływu wykształcenia może być pomocne, ponieważ zmienne $z$ tym związane mogą wpływać na skuteczność terapii. Jednakże jest oczywiste, że zbieranie informacji na temat wykształcenia może być trudne w kontekście rozgrywającej się katastrofy naturalnej. Zagadnienia te będą omówione później.
Kolejny czynnik, który może w znaczący sposób chronić przed stresem psychicznym, to wsparcie zarówno społeczne, jak i ze strony rodziny (Vernberg $\mathrm{i}$ in., 1996), a żadne $z$ opracowań nie uwzględniało tej zmiennej. Jednakże Fernandez (2007) umożliwiła rodzicom uczestniczenie wraz $\mathrm{z}$ dziećmi w sesjach terapeutycznych EMDR. Uwzględnienie tej zmiennej jest przydatne, gdyż obecność i wsparcie dorosłych w czasie terapii może ułatwić proces zdrowienia. $Z$ drugiej strony, katastrofy naturalne to zdarzenia majace wpływ na całe rodziny i społeczności. Dlatego lęki rodziców oraz innych dorosłych mogą oddziaływać na dziecii wzmacniać już istniejący dystres. Umożliwienie rodzicom wzięcia udziału w terapii może przynieść znaczące korzyści w tym zakresie. Rozważania na ten temat znalazły się również w opracowaniu Aduriza i in. (2011) - opisano tam uczestnictwo rodziców, nauczycieli i władz szkolnych $\mathrm{w}$ debriefingu oraz psychoedukacji. W nawiazaniu do społecznej teorii poznawczej (Benight \& Bandura, 2004, cytowane przez Watsona, 2007), istotną role w programie leczenia może odegrać udział osób ważnych dla pacjenta, dzięki czemu możliwe jest szybsze zmniejszenie dystresu, a dorosłym pozwala wypracować skuteczne metody radzenia sobie ze stresem $\mathrm{w}$ odniesieniu do dzieci (Watson, 2007).

W żadnym opracowaniu, oprócz Jarero i in. (2006), nie opisano zaburzeń psychicznych wystepujących przed leczeniem, a w jednym opracowaniu wykluczono udział osób, u których stwierdzono określone objawy. Mimo iż opracowania wykazały istotność statystyczną i kliniczną, w niektórych przypadkach część badanych pozostawała w narażona na duży stres $\mathrm{w}$ fazie badania kontrolnego (follow-up). Dlatego też dane dotyczace traumy nieprzetworzonej wcześniej oraz uprzednio wystepujących zaburzeń psychicznych, moga okazać sie pomocne w ocenie wpływu przeszłych traum na skuteczność terapii EMDR.

\section{Kliniczne implikacje oraz wyzwania w kontekście pracy z konsekwencjami katastrof naturalnych}

We wszystkich opracowaniach, w tym w czterech, których jakość określono jako „wysoką, wykazano statystyczną i kliniczną istotność terapii EMDR. Chociaż jakość pozostałych opracowań oceniono jako umiarkowaną bądź niska, to wyzwania związane $z$ potrzebami zdrowia psychicznego ofiar katastrof naturalnych ograniczają możliwości zwiększania metodologicznej jakości badań zgodnie z kryteriami RGS. Przykładowo, po katastrofach naturalnych zasoby naturalne są ograniczone (Gelbach, 2008), a tym samym zapewnienie 
obecności obiektywnych osób oceniających oraz stosowanie różnych narzędzi pomiarowych (oprócz tych wykorzystujących metode samoopisu) jest trudne.

Priorytetem po katastrofie naturalnej jest zaspokojenie podstawowych potrzeb zdrowia psychicznego ofiar oraz zapewnienie im psychoedukacji i stabilizacji. Dzięki temu takie osoby, przytłoczone negatywnym doświadczeniem, otrzymują wsparcie oraz możliwość właściwego przetworzenia traumatycznych wspomnień (Gelbach, 2008). Uzyskiwanie pełnej historii klinicznej, dokonywanie oceny uprzednio wystepujących zaburzeń psychicznych oraz ustalanie, czy osoby ocalone $z$ katastrof naturalnych są leczone w tym samym czasie za pomoca innego rodzaju terapii, jest zadaniem niemal niemożliwym do wykonania. Dlatego też uwzględniając kontekst, w którym działają terapeuci, w celu zwiększenia skuteczności metody EMDR, należy rekomendować stosowanie standardowego protokołu, odpowiedni poziom szkolenia terapeutów oraz regularne superwizje. Gelbach (2008) sugeruje również, by superwizorzy i badacze współpracowali przy opracowywaniu nowych metod, które mogłyby być udostepniane terapeutom i wdrażane w praktyce. Pomimo pewnych niedociagnięć metodologicznych opracowań ujętych $\mathrm{w}$ niniejszym przeglądzie, niezmiennie podkreśla się fakt wysokiej skuteczności metody EMDR w zmniejszaniu dystresu psychicznego u osób, które ucierpiały w katastrofach naturalnych.

Badania sugeruja, że kobiety są bardziej narażone na dystres psychiczny $\mathrm{w}$ nastepstwie katastrof naturalnych, ze względu na podział pracy uwarunkowany płcia, niski status społeczny i ekonomiczny oraz brak wpływów politycznych (Garrison i in., 1995). Opracowanie Aduriza i in. (2011) było jedynym, w którym opisano różnice wynikające z płci, stwierdzając, że kobiety są bardziej niż mę̇zzyźni narażone na negatywne skutki katastrof naturalnych w zakresie zdrowia psychicznego. W obliczu katastrofy podatność kobiet wzrasta tym bardziej, że rosną potrzeby zapewniania opieki, a maleje dostepność zasobów. Dlatego też reakcja na problemy psychiczne powinna uwzględniać różnice wynikające $z$ uwarunkowań związanych z płcia.

Chociażniniejszy przegląd przedstawia skuteczność terapii EMDR u osób, które przeżyły katastrofę naturalna, teoria COR Hobfolla (1989, cytowane przez Lo i in., 2012) zakłada, że istotną cześcią procesu powrotu do zdrowia jest wzmacnianie zasobów społecznych. Interwencje psychologiczne najcześciej oddziałuja na poziomie indywidualnym, natomiast katastrofy naturalne powodują szkody w dużej skali, które mają wpływ na całe społeczności oraz na kontekst strukturalny, w którym muszą żyć osoby, które wyszły cało $z$ takich katastrof. Celem terapii EMDR nie jest szeroko pojęte środowisko katastrofy, jednak można przyjać, że stabilne zdrowie psychiczne zwiększa zdolność jednostek do radzenia sobie w czasie katastrof oraz do odbudowy społeczności, gdy katastrofa minie. Ilustruje to studium przypadku opisane przez Jayatunge’a (2008), w którym EMDR umożliwia przywrócenie właściwego funkcjonowania psychospołecznego oraz prowadzenie przez osoby ocalone $\mathrm{z}$ katastrof normalnego i produktywnego życia.

\section{Wnioski}

Niniejszy przegląd przedstawia dowody na skuteczność metody EMDR w zmniejszaniu dystresu psychicznego u osób, które przeżyły katastrofe naturalną. Wszystkie uwzględnione tutaj opracowania wykazały statystyczną i kliniczną istotność terapii EMDR w tym zakresie. Niemniej jednak, opracowania te cechowała przeciętna jakość metodologii i sposób prowadzenia badań, co wpłyneło na ich ogólną jakość. Z drugiej strony, jak wspomniano wcześniej, sama natura tego typu katastrof sprawia, że trudno jest zastosować niektóre kryteria RGS. Dotyczy to m.in. obecności obiektywnych oceniajacych, stosowania szerokiego zakresu narzedzi pomiarowych (oprócz narzędzi opierających się na samoopisie) oraz identyfikacji istniejacych problemów psychicznych i udziału badanych osób $\mathrm{w}$ innych psychoterapiach $\mathrm{w}$ tym samym czasie. Jednakże mimo tych ograniczeń, skuteczność metody EMDR w przywracaniu prawidłowego funkcjonowania zdrowia psychicznego oraz fakt, iż jest to metoda pozwalająca oszczędzić zasoby, czas i nakłady finansowe sprawiaja, że wyżej wymienione zarzuty traca nieco swą siłe. Dodatkowym faktem, podkreślającym skuteczność terapii EMDR, jest brak pozytywnych rezultatów po zastosowaniu innych rodzajów terapii, co opisano w dwóch opracowaniach. Reasumując, wyniki uzyskane w niniejszym przeglądzie pozwalają twierdzić, że terapia EMDR powinna być zdecydowanie brana pod uwage jako skuteczna metoda interwencji dotycząca zdrowia psychicznego osób, które ocalały $z$ katastrof naturalnych.

\section{Piśmiennictwo}

Abbasnejad, M., Mehani, N. K., \& Zamyad, A. (2007). Efficacy of "eye movement desensitization and reprocessing" in reducing anxiety and unpleasant feelings due to earthquake experience. Psychological Research, 9, 104-117. 
Aduriz, M. E., Bluthgen, C., \& Knopfler, C. (2011). Helping child flood victims using group EMDR intervention in Argentina: Treatment outcome and gender differences. International Perspectives in Psychology, Research, Practice, Consultation, 1, 58-67. http://dx.doi .org/10.1037/2157-3883.1.S.58

Bisson, J., \& Andrew, M. (2009). Psychological treatment of post-traumatic stress disorder (PTSD). Cochrane Database of Systematic Reviews 2009, 3, 1-99. http:/ / dx.doi .org/ 10.1002/14651858.CD003388.pub3

Bisson, J. I., \& Deahl, M. P. (1994). Psychological debriefing and prevention of posttraumatic stress-More research is needed. British Journal of Psychiatry, 165, 717-720. http: / / dx.doi.org/10. 1192/bjp.165.6.717

Chemtob, C. M., Nakashima, J., \& Carlson, J. G. (2002). Brief treatment for elementary school children with disaster-related posttraumatic stress disorder: A field study. Journal of Clinical Psychology, 58, 99-112. http:// dx.doi.org/10.1002/jclp.1131

Davidson, P. R., \& Parker, K. C. H. (2001). Eye movement desensitization and reprocessing (EMDR): A metaanalysis. Journal of Consulting and Clinical Psychology, 69, 305-316. http:/ / dx.doi.org/ 10.1037/0022-006X.69.2. 305

De Roos, C., Greenwald, R., den Hollander-Gijsman, M., Noorthoorn, E., van Buuren, S., \& de Jongh., A. (2011). A randomised comparison of cognitive behavioural therapy (CBT) and eye movement desensitisation and reprocessing (EMDR) in disaster exposed children. European Journal of Psychotraumatology, 2, 1-11. http:/ / dx.doi.org/10. 3402/ ejpt.v2i0.5694

Fan, F., Zhang, Y., Yang, Y., Mo, L., \& Liu, X. (2011). Symptoms of posttraumatic stress disorder, depression, and anxiety among adolescents following the 2008 Wenchun earthquake in China. Journal of Traumatic Stress Studies, 24, 44-53. http: / / dx.doi.org/10.1002/jts.20599

Fernandez, I. (2007). EMDR as treatment of post-traumatic reactions: A field study on child victims of an earthquake. Educational and Child Psychology, 24, 65-73. Retrieved from http: / /www.coe.int/t/dg4/majorhaards / ressources / virtuallibrary/materials / italy / ECP\%20 fernandez.pdf

Fernandez, I., Gallinari, E., \& Lorenzetti, A. (2004). A school-based EMDR intervention for children who witnessed the Pirelli Building airplane crash in Milan, Italy. Journal of Brief Therapy, 2, 129-136. Retrieved from http: / / scholar.google.co.uk/scholar?hl=en \&q=A+sch oolbased+EMDR+intervention + for + children + who + witnessed + the + Pirelli + Building + airplane + crash + in + Milan $\% 2 C+$ Italy $\& b t n G=2$ as_sdt $=1 \% 2 \mathrm{C} 5 \%$ as_sdtp

Fernandez, I. (2007). EMDR as treatment of post-traumatic reactions: A field study on child victims of an earthquake. Educational and Child Psychology, 24, 65-73.

Foa, E. B., \& Meadows, A. (1997). Psychosocial treatments for posttraumatic stress disorder: A critical review. Annual Review Psychology, 48, 449-480. http://dx.doi .org/10.1146/ annurev.psych.48.1.449
Foa, E. B., Riggs, D. S., Dancu, C. V., \& Rothbaum, B. O. (1993). Reliability and validity of a brief instrument for assessing posttraumatic stress disorder. Journal of Traumatic Stress, 6, 459-473.

Garrison, C. Z., Bryant, E. S., Addy, C. L., Spurrier, P. G., Freedy, J. R., \& Kilpatrick, D. G. (1995). Posttraumatic stress disorder in adolescents after Hurricane Andrew. Journal of the American Academy of Child and Adolescent Psychiatry, 34, 1193-1201. http://dx.doi .org/10.1097/00004583-199509000-00017

Gelbach, R. A. (2008). Trauma, research, and EMDR: A disaster responder's wish list. Journal of EMDR Practice and Research, 2, 146-155. http://dx.doi .org/10.1891/1933-3196.2.2.146

Grainger, R. D., Levin, C., Allen-Byrd, L., Doctor R. M., \& Lee, H. (1997). An empirical evaluation of eye movement desensitization and reprocessing (EMDR) with survivors of a natural disaster. Journal of Traumatic Stress, 10, 665-667. http: / / dx.doi.org/10.1002/jts.2490100412

Horowitz, M. J., Wilner, N. R., \& Alvarez, W. (1979). Impact of event scale. A measure of subjective stress. Psychosomatic Medicine, 41, 209-218.

Ichii, M. (1997). Application of eye movement desensitization and reprocessing (EMDR) to survivors of the great Hanshin-Awaji earthquake: Treatment with less stress for stress disorder. Journal of Biofeedback Research, 24, 38-44. Retrieved from http: / / emdr.nku.edu/emdr_ subject.php?subject $=$ Natural\%20Disasters

Jarero, I., Artigas, L., \& Hartung, J. (2006). EMDR Integrative Group Treatment Protocol: A post-disaster trauma intervention for children and adults. Traumatology, 12, 121-129. http: / / dx.doi.org/10.1177/ 1534765606294561

Jarero, I., Artigas, L., \& Luber, M. (2011). The EMDR protocol for recent critical incidents: Application in a disaster mental health continuum of care context. Journal of EMDR Practice and Research, 5, 82-94. http://dx.doi .org/10.1891/1933-3196.5.3.82

Jayatunge, R. M. (2008). Combating tsunami disaster through EMDR. Journal of EMDR Practice and Research, 2, 140-145. http: / / dx.doi.org/10.1891/1933-3196.2.2.140

Jones, R. (1997). Child's reaction to traumatic events scale (CRTES). In Wilson, J., Keane, T. (Eds.), Assessing psychological trauma \& PTSD. New York, NY: Guilford Press.

Kar, N., \& Bastia, B. K. (2006). Post-traumatic stress disorder, depression and generalised anxiety disorder in adolescents after a natural disaster: A study of comorbidity. Clinical Practice and Epidemiology in Mental Health, 2, 1-7. http: / dx.doi.org/10.1186/1745-0179-2

Katz, C. L., Pellegrino, L., Pandya, A., Ng, A., \& DeLisi, L. E. (2002). Research on psychiatric outcomes and interventions subsequent to disasters: A review of the literature. Psychiatry Research, 110, 201-217. http:/ / dx.doi .org/10.1016/S0165-1781(02)00110-5

Kendler, K. S., Karkowski, L. M., \& Prescott, C. A. (1998). Stressful life events and major depression: Risk period, long-term contextual threat, and diagnostic specificity. 
Journal of Nervous and Mental Disease, 186, 661-669. http: / / dx.doi.org/10.1097/00005053-199811000-00001

Kirmayer, L. J., Lemelson, R., \& Barad, M. (2007). Understanding trauma. Integrating biological, clinical, and cultural perspectives. New York, NY: Cambridge University Press. Retrieved from http://books.google.co.uk/books?id= DXvpbu0tusMC\&printsec $=$ frontcover $\# \mathrm{v}=$ onepage $\& \mathrm{q}$ \&f $=$ false

Konuk, E., Knipe, J., Eke, I., Yuksek, H., Yurtsever, A., \& Ostep, S. (2006). The effects of eye movement desensitization and reprocessing (EMDR) therapy on posttraumatic stress disorder in survivors of the 1999 Marmara, Turkey, earthquake. International Journal of Stress Management, 13, 291-308. http:// dx.doi.org/10.1037/10725245.13.3. 291

La Greca, A. M., Silverman, W. K., \& Wasserstein, S. B. (1998). Children's predisaster functioning as a predictor of posttraumatic stress following Hurricane Andrew. Journal of Consulting and Clinical Psychology, 66, 883-892. http: / / dx.doi.org/10.1037/0022-006X. 66.6. 883

Lo, H. W. A., Su, C., \& Chou, F. H. (2012). Disaster psychiatry in Taiwan: A comprehensive review. Journal of Experimental and Clinical Medicine, 4, 77-81. http:/ /dx.doi .org/10.1016./j.jecm.2012.01.005

Maxfield, L., \& Hyer, L. (2002). The relationship between efficacy and methodology in studies investigating EMDR treatment of PTSD. Journal of Clinical Psychology, 58, 23-41. http: / / dx.doi.org/10.1002/jclp.1127

National Institute for Clinical Excellence. (2005). Posttraumatic stress disorder (PTSD): The management of PTSD in adults and children in primary and secondary care. London, United Kingdom: Author.

Neria, Y., Nandi, A., \& Galea, S. (2007). Post-traumatic stress disorder following disasters: A systematic review. Psychological Medicine, 38, 467-480. http://dx.doi .org/10.1017/S0033291707001353

North, C. S. (2007). Epidemiology of disaster mental health. In R. J. Ursano, C. S. Fullerton, L. Weisaeth, \& B. Raphael (Eds.), Textbook of disaster psychiatry (pp. 29-47). Cambridge, United Kingdom: Cambridge University Press. http: / / dx.doi.org/10.1017/ CBO9780511544415

North, C. S., Smith, E. M., \& Spitznagel, E. L. (1994). Posttraumatic stress disorder in survivors of a mass shooting. American Journal of Psychiatry, 151, 82-88. Retrieved from http: / / www.ncbi.nlm.nih.gov/pubmed/ 8267140

Norris, F. H., \& Wind, L. H. (2009). The experience of disaster: Trauma, loss, adversities, and community effects. In Y. Neria, S. Galea, \& F. H. Norris (Eds.), Mental health and disasters (pp. 29-45). New York, NY: Cambridge University Press. http://dx.doi.org/10.1017/ CBO9780511730030.003

Pollice, R., Bianchini, V., Roncone, R., \& Casacchia, M. (2011). Marked increase in substance use among young people after L'Aquila earthquake. European Child and Adolescent Psychiatry, 20, 429-430. http://dx.doi .org/10.1007/ s00787-011-0192-2
Pynoos, R. S., Frederick, C., Nader, K., Arroyo, W., Steinberg, A., \& Eth, S., et al. (1987). Life threat and posttraumatic stress in school-age children. Archives of General Psychiatry, 44, 1057-1063.

Roos, R., Benjamin, A., de Roos, C., Meijer, A. M., \& Stams, G. J. (2009). Efficacy of EMDR in children: A metaanalysis. Clinical Psychology Review, 2, 1-8. http:/ / dx.doi.org/10.1016/j.cpr.2009.06.008

Rubonis, A. V., \& Bickman, L. (1991). Psychological impairment in the wake of disaster: The disaster-psychopathology relationship. Psychological Bulletin, 3, 384-399. http:/ / dx.doi .org/10.1037/0033-2909.109.3.384

Seidler, G. H., \& Wagner, F. E. (2006). Comparing the efficacy of EMDR and trauma-focused cognitive-behavioral therapy in the treatment of PTSD: A meta-analytic study. Psychological Medicine, 36(11), 1515-1522. http://dx.doi .org/10.1017/S0033291706007963

Shapiro, F. (1995). Eye Movement Desensitization and Reprocessing: Basic Principles, Protocols, and Procedures. New York: Guilford Press.

Shapiro, F. (2001). Eye Movement Desensitization and Reprocessing, Basic Principles, Protocols and Procedures. (2nd ed.). New York: The Guilford Press.

Shapiro, F., \& Maxfield, L. (2002). Eye movement desensitization and reprocessing (EMDR): Information processing in the treatment of trauma. Psychotherapy in Practice, 58, 933-946. http: / / dx.doi.org/10.1002/jclp.10068

Solomon, R. M., \& Shapiro, F. (2008). EMDR and the adaptive information processing Model: Potential mechanisms of change. Journal of EMDR Practice and Research, 2, 315-325. http: / / dx.doi.org/10.1891/1933-3196.2.4.315

Terranova, A. M., Boxer, P., \& Morris, A. S. (2009). Factors influencing the course of posttraumatic stress following a natural disaster: Children's reactions to Hurricane Katrina. Journal of Applied Developmental Psychology, 30, 3440355. http://dx.doi.org/10.1016/j .appdev.2008.12.017

Ursano, R. J., Fullerton, C. S., Weisaeth, L., \& Raphael, B. (2007). Individual and community responses to disasters. In R. J. Ursano, C. S. Fullerton, L. Weisaeth, \& B. Raphael (Eds.), Textbook of disaster psychiatry (pp. 3-26). New York, NY: Cambridge University Press. http:// dx.doi.org/10.1017/CBO97 80511544415

Van Rood, Y. R., \& de Roos, C. (2009). EMDR in the treatment of medically unexplained symptoms: A systematic review. Journal of EMDR Practice and Research, 3, 248-263. http: / / dx.doi.org/ 10.1891/1933-3196.3.4.248

Vernberg, E. M., La Greca, A. M., Silverman, W. K., \& Prinstein, M. J. (1996). Prediction of post-traumatic stress symptoms in children after Hurricane Andrew. Journal of Abnormal Psychology, 105, 237-248.

Watson, P. J. (2007). Early intervention for trauma-related problems following mass trauma. In R. J. Ursano, C. S. Fullerton, L. Weisaeth, \& B. Raphael (Eds.), Textbook of disaster psychiatry (pp. 121-139). New York, NY: Cambridge University Press. http: / / dx.doi.org/10.1017/ CBO9780511544415 